\title{
Experimental Study on the Performance of Circular Concrete Columns Reinforced with GFRP under Axial Load
}

\author{
Sherif El Gamal \\ sherif@squ.edu.om \\ College of Engineering, Sultan Qaboos University, Muscat, Oman \\ Othman Alshareedah \\ othman.alshareedah@wsu.edu \\ College of Engineering, Washington State University, USA
}

\begin{abstract}
Corrosion of steel reinforcement in concrete structures subjected to severe environments is a big challenge and requires huge repair and maintenance costs. Glass fiber reinforced polymer (GFRP) reinforcement with its corrosion resistance and good mechanical properties is a promising solution to replace steel in such structures. This paper investigates the efficiency of using GFRP bars and spirals in concrete columns instead of conventional steel reinforcement. Five circular concrete columns of $230 \mathrm{~mm}$ diameter and $1500 \mathrm{~mm}$ height reinforced with different types and ratios of reinforcement were constructed and tested under concentric load. Test parameters included the type and ratio of the longitudinal reinforcement. The results showed that the columns reinforced with GFRP behaved in a similar way as the reference columns reinforced with steel, however, they showed slightly lower nominal capacity. It was also found that increasing the GFRP longitudinal reinforcement ratio enhanced the nominal capacity of the columns.
\end{abstract}

Keywords: GFRP reinforcement; Circular concrete column; Reinforcement ratio; Concentric load

\section{INTRODUCTION}

Corrosion of steel reinforcement is the main reason for concrete structures deterioration in harsh environments. In 1998, steel corrosion-related problems caused a direct cost of $\$ 276$ billion in the United States (Koch et al., 2002). Fiber Reinforced Polymers (FRP) with their non-corrosive nature, high strength, and lightweight encouraged their use instead of steel reinforcement in concrete structures to avoid the steel corrosion problems (Al-Salloum et al., 2013; El-Gamal et al., 2016; El-Gamal et al., 2019). This includes several field applications such as bridge deck slabs, parking garages and concrete pavements (Benmokrane et al., 2007; El-Gamal et al., 2009; Thébeau et al., 2010; Bouguerra et al., 2011; Benmokrane et al., 2008). However, most of the FRP bars in these field applications were used in flexural members and there is a need to extend their use in compression members such as columns as well.

In recent years, researchers started to investigate the behavior of concrete columns reinforced with FRP (FRP-RC columns). Maranan et al. (2016) studied the behavior of Glass FRP (GFRP) RC columns under concentric load. Circular columns with $1000 \mathrm{~mm}$ height and $250 \mathrm{~mm}$ diameter were cast with $38 \mathrm{MPa}$ geopolymer concrete and reinforced with longitudinal GFRP bars and stirrups. The test results showed that before the spalling 
of concrete cover, the GFRP bars' contribution in the axial capacity varied from $6.6 \%$ to $10.5 \%$ for the columns with a $2.43 \%$ reinforcement ratio. Moreover, considering stirrups configuration, specimens with less spacing revealed more ductile failure mode and higher confinement efficiency compared with columns reinforced with higher stirrups spacing. Tobbi et al. (2014) explored the behavior of concrete columns reinforced with GFRP under concentrated axial load. Rectangular columns with $350 \mathrm{~mm}$ cross-section and $1400 \mathrm{~mm}$ height were constructed with $30 \mathrm{MPa}$ grade concrete. The research parameters were longitudinal reinforcement ratio, transverse reinforcement spacing, reinforcement material, and diameter. It was observed that modes of failure depended on the lateral reinforcement configuration and spacing as well as the material of longitudinal bars. Columns reinforced with GFRP failed by bar crushing or buckling and stirrups rupture while steel-RC columns failed by excessive bar buckling. Furthermore, increasing the reinforcement ratio increased the peak load before the activation of confinement. The study stated that the steel-RC columns achieved higher peak loads compared to the GFRP-RC columns with the same reinforcement ratio. Also, the axial strain of the GFRP-RC columns was lower than the steel-RC columns by $30 \%$. Similar conclusions were reported by Afifi et al. (2013) where they tested circular columns with $300 \mathrm{~mm}$ diameter and $1500 \mathrm{~mm}$ height and $42.9 \mathrm{MPa}$ concrete compressive strength. The study revealed that GFRP-RC columns with low stirrups spacing failed by either concrete crushing or stirrups rupture. Besides, GFRP-RC columns reached an ultimate capacity lower than steel RC columns by about $7 \%$ on average. Higher ductility and lower postpeak strength decay were exhibited by GFRP-RC columns. The contribution of GFRP bars in the peak load was between 5 to $10 \%$ while the contribution of steel bars was $16 \%$ of the peak load. Tavassoli (2013) showed that GFRP-RC columns can accommodate more axial cyclic loading than the same columns reinforced with steel. This is due to the large buckling of steel reinforcement after the yield strain, unlike GFRP reinforcement where it can reach larger strain values before failure. Lotfy (2010) found that increasing the FRP longitudinal reinforcement ratio from $0.72 \%$ to $1.08 \%$ resulted in higher loading capacity with a magnitude larger than increasing the reinforcement ratio from $1.08 \%$ to $1.45 \%$. Castro et al. (1995) found that the FRP contribution in the ultimate capacity of low-grade concrete columns subjected to buckling was more significant than high-grade concrete columns.

It can be noted that previous studies concentrated on investigating the behavior GFRP-RC columns with normal strength concrete and there is a lack of research studies that investigate the behavior of GFRP-RC columns with low strength concrete. This is covered in this research study where the behavior of low strength concrete GFRP-RC columns under concentric axial load is investigated. The study parameters include the type of reinforcement (Steel and GFRP) and the longitudinal reinforcement ratio.

\section{EXPERIMENTAL WORK}

\subsection{Test Specimens}

Five circular concrete columns of $230 \mathrm{~mm}$ diameter and $1500 \mathrm{~mm}$ height were constructed. The specimens were divided into two groups based on each study parameter as shown in Table 1. The first group was designed to study the effect of reinforcing material. The S1 column was reinforced with steel bars and spirals while S2 was reinforced with steel bars and GFRP spirals. G1 column was fully reinforced with GFRP 
bars and spirals. Group 2 columns were designed to investigate the effect of the GFRP longitudinal reinforcement ratio. The reinforcement ratio was increased from $1.63 \%$ in G1 to $2.17 \%$ and $3.87 \%$ in G2 and G3, respectively. The spirals spacing was fixed to 75 $\mathrm{mm}$ in all columns. At the top and bottom $250 \mathrm{~mm}$ portion, the spacing of the spirals was reduced to $50 \mathrm{~mm}$ to provide more confinement at the ends and avoid premature failure.

\subsection{Materials}

Ready-mix concrete with an average compressive strength of $25.6 \mathrm{MPa}$ and average tensile strength of 2.3 MPa was used. GFRP bars and spirals fabricated by a company in Dubai (Pultron Composites) were used in this study. Figure 1 shows photos of both the GFRP longitudinal bars and spirals. The longitudinal bars and the spirals were fabricated using two different techniques. The longitudinal bars and straight bars of the spirals were tested in tension to obtain their mechanical properties. The tensile tests were conducted according to ACI 440-3R guide (ACI 440, 2004) as illustrated in Figure 2. Table 2 shows the mechanical properties of GFRP bars and spirals.

Table 1: Details of Test Specimens

\begin{tabular}{|c|c|c|c|c|}
\hline \multirow{2}{*}{ Group } & \multirow{2}{*}{ Specimen } & \multicolumn{2}{|c|}{ Longitudinal Reinforcement } & Spirals \\
\cline { 3 - 5 } & & Material & Size $($ Ratio $\%)$ & Material $(\mathrm{size})$ \\
\hline \multirow{3}{*}{ I } & S1 (6S12-S75) & Steel & $6 \varphi 12(1.63 \%)$ & Steel $(\varphi 10 @ 75 \mathrm{~mm})$ \\
\cline { 2 - 5 } & S2 (6S12-G75) & Steel & $6 \varphi 12(1.63 \%)$ & GFRP $(\varphi 10 @ 75 \mathrm{~mm})$ \\
\cline { 2 - 5 } & G1 (6G12-G75) & GFRP & $6 \varphi 12(1.63 \%)$ & GFRP $(\varphi 10 @ 75 \mathrm{~mm})$ \\
\hline \multirow{3}{*}{ II } & G1 (6G12-G75) & GFRP & $6 \varphi 12(1.63 \%)$ & GFRP $(\varphi 10 @ 75 \mathrm{~mm})$ \\
\cline { 2 - 5 } & G2 (8G12-G75) & GFRP & $8 \varphi 12(2.17 \%)$ & GFRP $(\varphi 10 @ 75 \mathrm{~mm})$ \\
\cline { 2 - 5 } & G3 (8G16-G75) & GFRP & $8 \varphi 16(3.87 \%)$ & GFRP $(\varphi 10 @ 75 \mathrm{~mm})$ \\
\hline
\end{tabular}

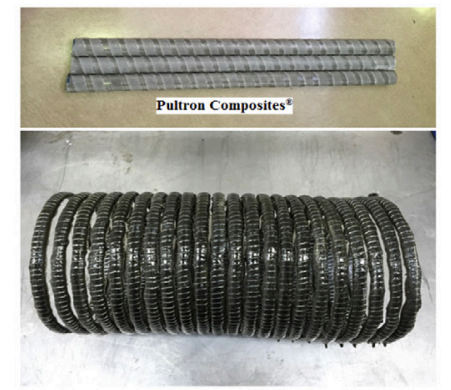

Figure 1: GFRP reinforcement used in this study

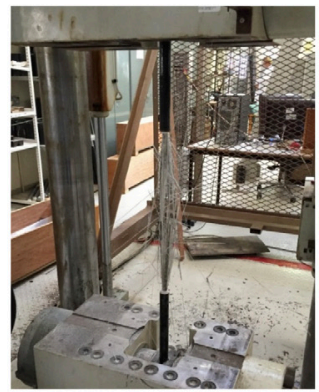

Figure 2: Tensile testing of GFRP bars

Table 2: Tensile test results for GFRP specimens

\begin{tabular}{|l|l|l|l|l|l|l|}
\hline Type of GFRP & $\begin{array}{l}\text { Nominal } \\
\text { Diameter } \\
(\mathrm{mm})\end{array}$ & $\begin{array}{l}\text { Exterior } \\
\text { Diameter } \\
(\mathrm{mm})\end{array}$ & $\begin{array}{l}\text { Cross- } \\
\text { sectional } \\
\text { area }\left(\mathrm{mm}^{2}\right)\end{array}$ & $\begin{array}{l}\text { Fracture } \\
\text { Strain }\end{array}$ & $\begin{array}{l}\text { Tensile } \\
\text { Strength } \\
(\mathrm{MPa})\end{array}$ & $\begin{array}{l}\text { Elastic } \\
\text { Modulus } \\
(\mathrm{GPa})\end{array}$ \\
\hline $\begin{array}{l}\text { Longitudinal } \\
\text { Bar }\end{array}$ & 12 & 12.8 & 128.6 & $1.8 \%$ & 1191 & 63.3 \\
\hline $\begin{array}{l}\text { Longitudinal } \\
\text { Bar }\end{array}$ & 16 & 15.9 & 198.56 & $1.8 \%$ & 1102 & 61.2 \\
\hline Spirals & 12 & 12.8 & 128.6 & $2.2 \%$ & 1345 & 60.9 \\
\hline
\end{tabular}


Deformed steel bars and spirals were purchased from a local supplier in Oman. The longitudinal bar diameter was $12 \mathrm{~mm}$ while the spiral stirrups diameter was $10 \mathrm{~mm}$. Tensile tests were performed on steel specimens of both diameters to obtain their yield strength and tensile modulus. The results of the test are illustrated in Table 3.

Table 3: Tensile test results for steel bars and stirrups

\begin{tabular}{|l|c|c|c|c|}
\hline Type & $\begin{array}{l}\text { Nominal } \\
\text { Diameter }(\mathrm{mm})\end{array}$ & $\begin{array}{l}\text { Cross-sectional } \\
\text { area } \\
\left(\mathrm{mm}^{2}\right)\end{array}$ & $\begin{array}{l}\text { Tensile Strength } \\
(\mathrm{MPa})\end{array}$ & $\begin{array}{l}\text { Elastic Modulus } \\
(\mathrm{GPA})\end{array}$ \\
\hline Longitudinal bars & 12 & 113 & 451 & 209 \\
\hline Stirrups & 10 & 78.5 & 446 & 210 \\
\hline
\end{tabular}

\subsection{Construction of Test Specimens}

The reinforcement cages were prepared using two wooden holders to align the bars straight in their positions inside the spirals. The spirals were stretched to the desired spacing and then fixed with the longitudinal bars via steel binding wires. Plastic pipes with an internal diameter of $230 \mathrm{~mm}$ and $1500 \mathrm{~mm}$ height were used as formworks. The pipes were placed in a wooden structure designed to stabilize the columns during construction and concrete casting as shown in Figure 3. The reinforcement cages were placed inside the pipes and concrete cookies were used to maintain the concrete cover. After the concrete was cast and hardened, the pipes were cut using an electrical saw to remove them and take out the concrete columns to start the curing process for 28 days before testing.

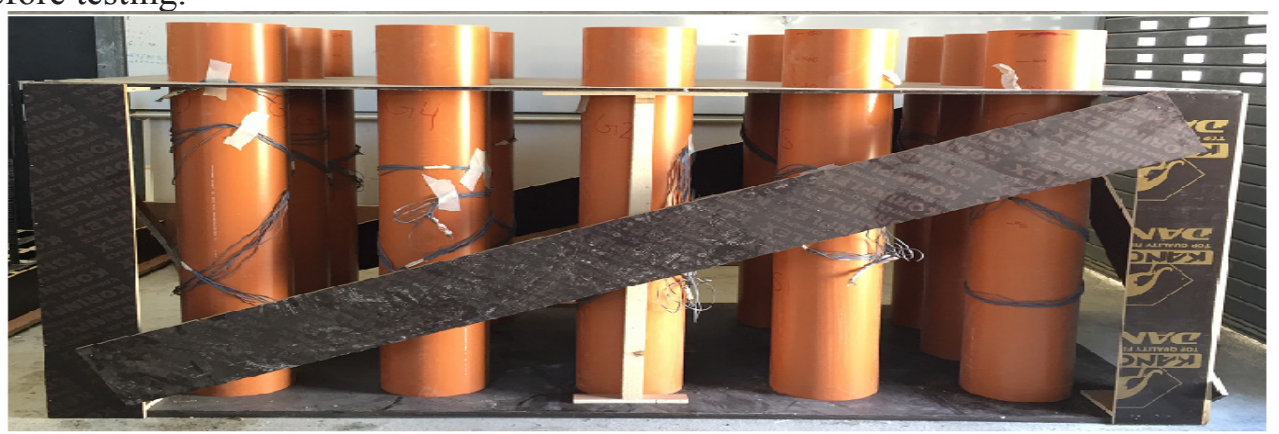

Figure 3: Formwork ready for concrete casting

\subsection{Test Setup and Instrumentation}

Several strain gauges were installed on the longitudinal and transverse reinforcement to measure the strains in the reinforcement during testing. In addition, six strain gauges were installed on the surface of the concrete at mid-height of the columns in the longitudinal and hoop direction to measure concrete strains. Furthermore, a Linear Variable Differential Transformer (LVDT) was used to measure the total axial deformations of the columns. Two steel caps were used to confine both ends of the columns to prevent premature failure at the ends due to high stresses. The axial loads were applied using a $4000 \mathrm{kN}$ testing machine under a displacement control of $1 \mathrm{~mm} /$ min loading rate until failure. Figure 4 shows a schematic drawing of the locations of strain gauges and the testing set-up. 


\section{TEST RESULTS AND DISCUSSIONS}

All tested columns experienced three different stages. The first stage starts with the initial loading until reaching the first peak load and hairline cracks appear on the surface of the concrete. The first peak load will be considered the nominal capacity $\left(P_{n}\right)$ of the columns. The second stage starts after reaching the $P_{n}$ until reaching the maximum load $\left(P_{\max }\right)$. The third stage starts after reaching the $P_{\max }$ until the total collapse of the columns. Figure 5 shows the three stages and Table 4 summarizes the test results of all tested columns.
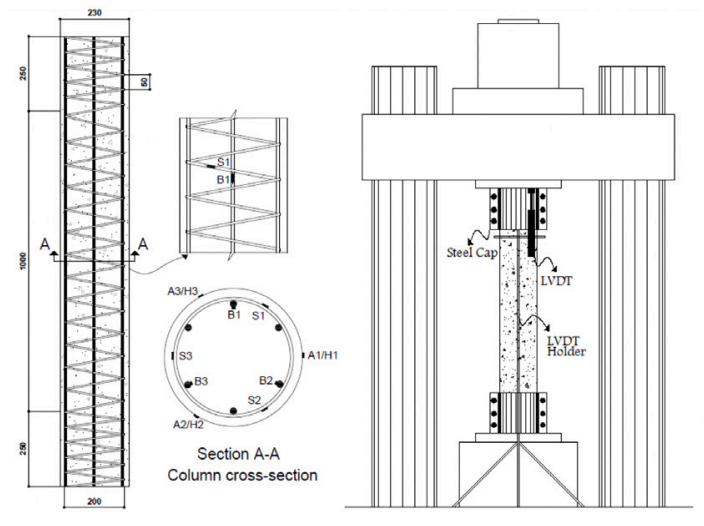

Figure 4: Instrumentation and testing set-up

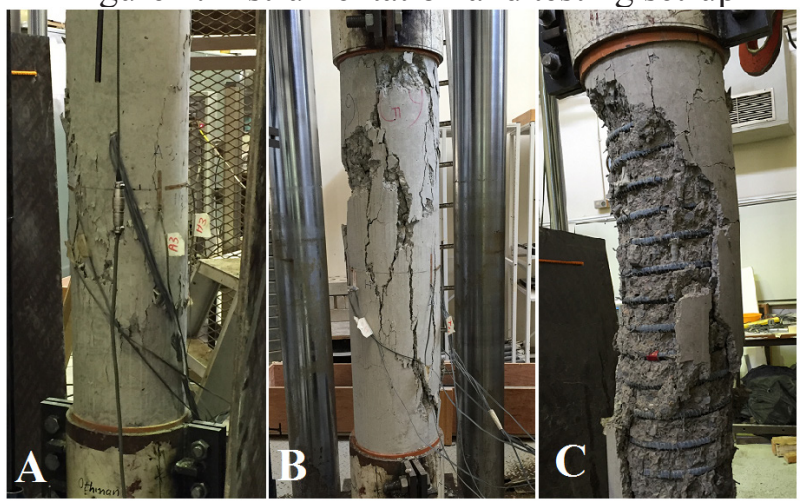

Figure 5: (a) First phase; (b) Second phase; (c) Third phase

\subsection{Effect of Reinforcement Type}

Test results of Group I specimens that have the same amount but different types of reinforcement show that columns S1 (totally reinforced with steel) and column S2 (reinforced with longitudinal steel bars and GFRP spirals) had the same nominal capacity. Columns G1 (totally reinforced with GFRP) showed about 6.7\% lower nominal capacity compared to both S1 and S2. This lower capacity can be attributed to the lower elastic modulus of GFRP bars compared to steel bars, which results in less contribution of the GFRP longitudinal reinforcement to the capacity of the columns. The G1 column, however, showed almost similar maximum capacity as S1 and S2 columns. This can be attributed to the linear behavior of the GFRP reinforcement, which continues to support loads until reaching their ultimate strain. 
Table 4: Test results of all specimens

\begin{tabular}{|c|c|c|c|c|c|c|c|c|c|c|}
\hline \multirow{2}{*}{ Group } & \multirow{2}{*}{$\begin{array}{l}\text { Spec- } \\
\text { imen }\end{array}$} & \multirow{2}{*}{$\begin{array}{c}P_{n} \\
(\mathrm{kN})\end{array}$} & \multirow{2}{*}{$\begin{array}{l}P_{\max } \\
(\mathrm{kN})\end{array}$} & \multirow{2}{*}{$\begin{array}{c}\Delta_{P n} \\
(\mathrm{~mm})\end{array}$} & \multirow{2}{*}{$\begin{array}{r}\Delta_{P \max } \\
(\mathrm{mm})\end{array}$} & \multirow{2}{*}{$\begin{array}{c}\varepsilon_{\mathrm{t}} \\
(\mu)\end{array}$} & \multicolumn{2}{|c|}{$\begin{array}{l}\text { Reinforcement } \\
\text { Strains }\left(\text { at } P_{n} \text { ) }\right.\end{array}$} & \multirow{2}{*}{$\begin{array}{c}\text { Concrete } \\
\text { strains } \\
\varepsilon_{\mathrm{c}}^{* *} \\
(\mu)\end{array}$} & \multirow{2}{*}{ Failure Mode } \\
\hline & & & & & & & $\begin{array}{c}\varepsilon_{\text {bar }}^{*} \\
(\mu)\end{array}$ & $\begin{array}{c}\varepsilon_{\text {stirups }} * \\
(\mu)\end{array}$ & & \\
\hline \multirow[t]{3}{*}{ I } & S1 & 1139 & 1203 & 3.2 & 5.5 & 2133 & 2163 & 493 & 2465 & \multirow{2}{*}{$\begin{array}{c}\text { Buckling of Bars } \\
\rightarrow \mathrm{CC}\end{array}$} \\
\hline & S2 & 1140 & 1183 & 4.0 & 10.8 & 2666 & 2041 & 521 & 2769 & \\
\hline & G1 & 1063 & 1197 & 4.6 & 7.1 & 3066 & 4985 & 3818 & 2127 & \multirow{3}{*}{$\begin{array}{c}\text { Crushing of Long. } \\
\text { Bars } \rightarrow \text { CC }\end{array}$} \\
\hline \multirow[t]{3}{*}{ II } & G1 & 1063 & 1197 & 4.5 & 7.1 & 3000 & 4985 & 3818 & 2127 & \\
\hline & $\mathrm{G} 2$ & 1190 & 1536 & 6.6 & 17.6 & 4400 & 3997 & 2001 & 2035 & \\
\hline & G3 & 1227 & 1457 & 5.5 & 10.7 & 3666 & 3670 & 2321 & 2149 & $\mathrm{CC}$ \\
\hline
\end{tabular}

Figure 6(a) shows that column G1 exhibited lower initial axial stiffness compared to $\mathrm{S} 1$ and S2, which resulted in higher axial displacement at $P_{n}$. In addition, it is worth noting that the G1 column showed less ductile behavior compared to the steel-reinforced columns. Figure 6(b) shows that the strains in the longitudinal bars of S1 and S2 were similar up to steel yielding. The longitudinal steel bars in S1 and S2 columns yielded at load values very close to their $P_{n}$ (about $1140 \mathrm{kN}$ ). The corresponding longitudinal strains in the bars were about 2163 and 2041 microstrain (Table 4), which are very close to the yield strain of the steel bars. After steel yielding, columns S1 shows a slight increase (5.6\%) in the axial load while column S2 shows only a 3.7\% increase in the $P_{\max }$ compared to its $P_{n}$. Figure 6(b) shows also that G1 exhibited higher axial compressive strains in the longitudinal bars compared to $\mathrm{S} 1$ and $\mathrm{S} 2$ columns. The maximum recorded bar compressive strains at failure were about 10000 micro-strain in G1, which were about $55 \%$ of the ultimate tensile strain of the GFRP bars.

Table 4 shows that columns S1 and S2 had almost similar strains in the spirals (493 and 521 micro-strain) at $P_{n}$. These strains were less than $25 \%$ of the yield strain of steel. They were also much lower than the spirals strains recorded in G1 column (3818 microstrain) which were only $18 \%$ of the ultimate tensile strain of the GFRP bars. This indicates that the stirrups were not actively utilized at this stage of loading. The spirals strains in the three columns increased significantly after exceeding the $P_{n}$ where concrete cores expand and dilate thus applying more tensile stresses on the transverse reinforcement. At collapse, spirals strains of about 6500 to 6800 micro-strain were recorded in S2 and G1, respectively. These values were twice the strains recorded in the steel spirals in S1 and were about $30 \%$ of the ultimate strain of the GFRP reinforcement. The higher recorded strains in the GFRP spirals accompanied by the increase in the axial load mean that the spirals continued to confine the columns until failure.

\subsection{Effect of Reinforcement Ratio}

Table 4 shows that the nominal capacities of G1, G2, and G3 were 1063, 1190 and $1227 \mathrm{kN}$ respectively. This indicates that increasing the longitudinal reinforcement ratio increased the $P_{n}$ of the columns. However, this increase was not linear. Increasing the reinforcement ratio from $1.63 \%$ in G1 to $2.17 \%$ in G2 increased the $P_{n}$ by $11.9 \%$ while 
increasing the ratio to $3.87 \%$ in G3 increased the $P_{n}$ by only $15.4 \%$ compared to G1 column and by only $3 \%$ compared to G2 column. The results of the $P_{n}$ reveal that it is not efficient or economical to use very high GFRP reinforcement ratios in RC columns.

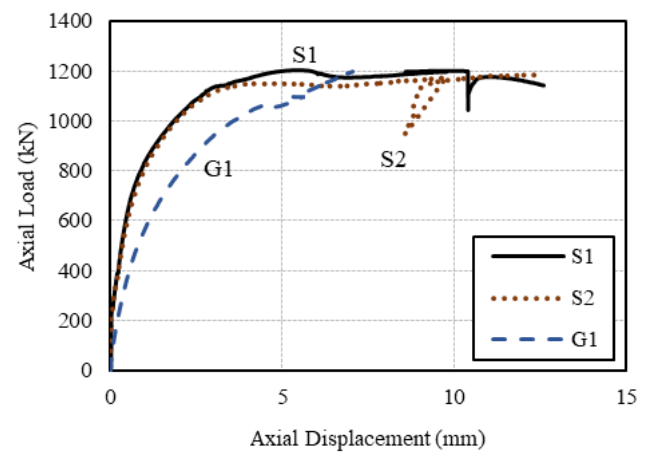

(a)

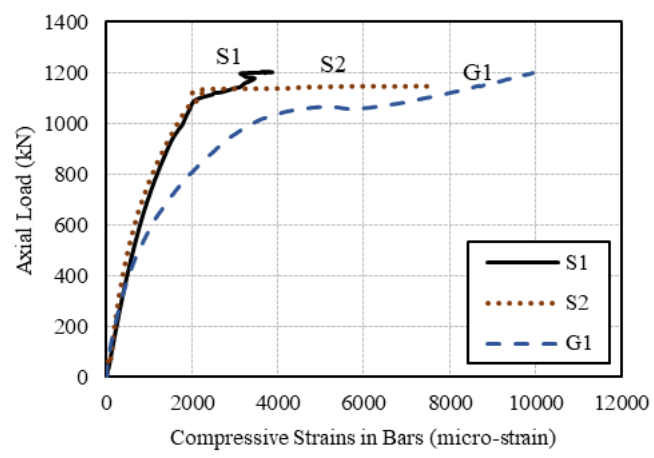

(b)

Figure 6: Effect of reinforcement type; (a) load-vertical displacement; (b) loadcompressive strains in longitudinal bars

Crushing of longitudinal bars was recorded in G1 and G2 columns while G3 failed by concrete core crushing. This could be attributed to the larger reinforcement ratio and the larger diameter of GFRP bars used in G3 $(16 \mathrm{~mm})$ compared to the $12 \mathrm{~mm}$ diameter bars used in G1 and G2. Figure 7(a) shows the load-vertical displacement curves of G1, $\mathrm{G} 2$, and G3. The three columns showed almost similar behavior until reaching the $P_{n}$ of each column. Column G2 showed the highest $P_{\max }(1457 \mathrm{kN})$ among the three specimens while specimen G1 showed the lowest $P_{\max }(1197 \mathrm{kN})$.

Figure 7(b) and Table 4 shows that the strains corresponding to $P_{n}$ of each column decreased as the reinforcement ratio increased. The strains in longitudinal bars increased rabidly after exceeding the $P_{n}$. At failure, the highest longitudinal bars strains in the three columns were recorded in the G2 column with more than 16200 micro-strain, which were about $90 \%$ of the ultimate tensile strain of the GFRP bars. It was observed that the G3 column showed the lowest longitudinal bars strain at $P_{n}$ (3670 microstrain) among all GFRP-RC columns due to its higher reinforcement ratio compared to other columns.

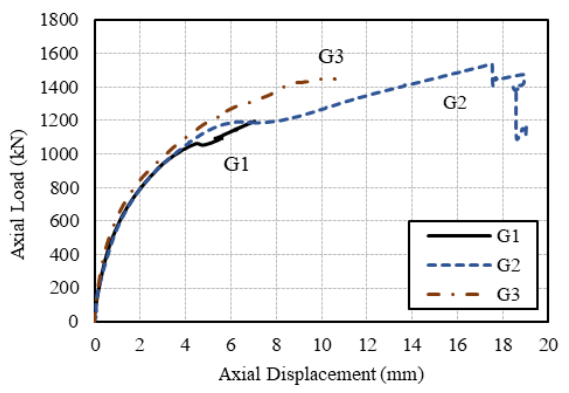

(a)

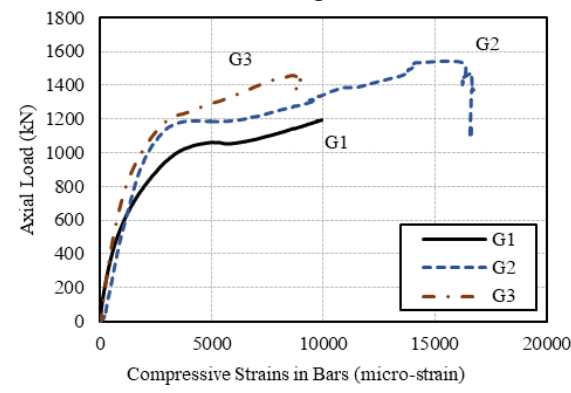

(b)

Figure 7: Effect of reinforcement ratio; (a) load-vertical displacement; (b) loadcompressive strains in longitudinal bars 


\section{CONCLUSION}

Steel-RC columns failed by steel buckling followed by concrete crushing, while most of the GFRP-RC columns failed by crushing of GFRP bars accompanied with concrete crushing. The nominal capacity $\left(P_{n}\right)$ of the GFRP-RC column was about $6.7 \%$ lower than the nominal capacities of the steel-RC columns whereas the maximum capacities $\left(P_{\max }\right)$ were almost similar. Increasing the longitudinal reinforcement ratio in the GFRP-RC columns resulted in higher $P_{n}$. The steel-RC columns sustained approximately constant load after the first peak while the axial deformations and strains increased gradually. On the contrary, GFRP-RC columns showed a continuous increase in the load after the first peak coupled with an increase in the axial deformations and strains until failure.

\section{REFERENCES}

Afifi, M. Z., Mohamed, H. M. \& Benmokrane, B. (2013). Axial capacity of circular concrete columns reinforced with GFRP bars and spirals. Journal of Composites for Construction, $18(1)$.

Al-Salloum, Y., El-Gamal, S., Almusallam, T., Alsayed, S., Aqel, M. (2013). Effect of Harsh Environmental Conditions on the Tensile Properties of GFRP Bars. Composites: Part B, 45(1): 835-844.

American Concrete Institute Committee 440 (2004). Guide Test Methods for Fiber-Reinforced Polymer (FRP) Composites for Reinforcing or Strengthening Concrete and Masonry Structures. (ACI 440.3R-04). American Concrete Institute, Farmington Hills.

Benmokrane, B., El-Salakawy, E., El-Ragaby, A. \& El-Gamal, S.E. (2007). Performance evaluation of innovative concrete bridge deck slabs reinforced with fiber-reinforced-polymer bars. Canadian Journal of Civil Engineering, 34(3), 298-310.

Benmokrane. B., Eisa. M., El-Gamal, S. E., Denis Thébeau \& El-Salakawy. E. (2008). Pavement System Suiting Local Conditions. ACI Concrete International Magazine, November, pp. 3439.

Bouguerra, K., Ahmed E. A., El-Gamal, S. E. \& Benmokrane, B. (2011). Testing of full-scale concrete bridge deck slabs reinforced with fiber reinforced polymer (FRP) bars. Construction and Building Materials Journal, Vol. 25, 3956-3965.

Castro, P. F., Howie, I. \& Karbhari, V. (1995). Concrete columns reinforced with FRP rods. International Journal of Materials and Product Technology, 10(3-6), 338-343.

El-Gamal S. E., Al-Nuaimi A. S., Al-Saidy A. H. \& Al-Lawati A. (2016) Efficiency of Near Surface Mounted Technique Using Fiber Reinforced Polymers for the Flexural Strengthening of RC Beams. Construction and Building Materials Journal, Elsevier, Vol. 118: 52-62.

El-Gamal S. E., Al-Nuaimi A. S., Al-Saidy A. H. \& Al-Shanfari K. (2019) Flexural behavior of RC beams strengthened with CFRP sheets using different strengthening techniques. The Journal of Engineering Research, Vol. 16 (1): 35-43.

El-Gamal, S. E., Benmokrane, B. \& El-Salakawy, E. F. (2009). Cracking and deflection behavior of one-way parking garage slabs reinforced with CFRP bars. ACI Special Publication, SP264-3, 33-52.

Koch, G. H., Brongers, M. P., Thompson, N. G., Virmani, Y. P. \& Payer, J. H. (2002). Corrosion cost and preventive strategies in the United States. FHWA-RD-01-156.

Lotfy, E. M. (2010). Behavior of reinforced concrete short columns with Fiber Reinforced 
polymers bars. International Journal of Civil and Structural Engineering, 1(3), 545-557.

Maranan, G. B., Manalo, A. C., Benmokrane, B., Karunasena, W. \& Mendis, P. (2016). Behavior of concentrically loaded geopolymer-concrete circular columns reinforced longitudinally and transversely with GFRP bars. Engineering Structures, 117:422-436.

Tavassoli, A. (2013). Behavior of GFRP-reinforced concrete columns under combined axial load and flexure. (M.Sc. degree dissertation, University of Toronto).

Thébeau, D., Benmokrane, B. \& El-Gamal S. E. (2010). Three-year performance of continuously reinforced concrete pavement with GFRP bars. 11th International Symposium on Concrete Roads, Seville, Spain, October 13-15, p. 11.

Tobbi, H., Farghaly, A. S. \& Benmokrane, B. (2014). Behavior of concentrically loaded FiberReinforced Polymer Reinforced Concrete Columns with varying reinforcement types and ratios. ACI Structural Journal, 111(2). 